\title{
THE IMPACT OF CORPORATE CULTURES AND FINANCIAL RATIOS ON THE FRAUDULENT FINANCIAL REPORTING
}

\author{
Agung Prajanto* \\ Ririh Dian Pratiwi \\ Universitas Dian Nuswantoro
}

\begin{abstract}
This study aims to examine and analyze financial statement fraud through financial ratios and corporate culture, case study of companies listed on the Indonesia Stock Exchange Year 2006-2010. The research was conducted at the companies included in the sanctions issued by Capital Markets Supervisory Board (Bapepam) in the period 2006-2010 for companies that committed fraud. While for the companies that did not do fraud, sample was obtained randomly by same asset and industry size. Testing was conducted by using logistic regression to determine the effect of financial ratios and corporate culture on financial statements fraud. Results of research conducted using logistic regression showed that liquidity ratio had positive effect on fraudulent financial statements. While the ratio of gross profit margin and capital turnover indicated a negative impact on financial reporting fraud. Variable of corporate culture was proxied by special relationship transaction, the composition of the founders in board of directors and directors who titled accountant did not effect on fraudulent financial statements.
\end{abstract}

Keywords: financial statements; fraud; financial ratio; corporate culture

\section{INTRODUCTION}

Accounting fraud is a problem of social and economic concerns. The impacts of accounting fraud have made many people suffered. Accounting fraud case that emerged recently is an audit failure which is fatal for the business community (Koroy, 2008). A chamber of commerce in the United States noted that loses because of fraud reached \$ 100 Billion (Glover, et al, 1995 in Limming Guan, et al 2007). This opinion was reinforced by Sphatis (2002) in Wiloppo (2006), which explains that in the United States, accounting fraud resulted in large losses in almost all the industries in that country.

Systematically The Association of Certified Fraud Examiners (ACFE) describes the fraudulent activity consists of corruption, misappropriation of assets and fraudulent financial reporting. Corruption is a form of fraudulent that is done because of the shape of behalf, bribery, gifts unlawful, extortion, (Tuanakotta, 2007). Misappropriation asset involves such things as fraud, theft, padding expense accounts and other misappropriation of corporate assets. The last, the form of fraud in financial reporting that occurred was done with the scheme of falsification, alteration or manipulation of financial records.

Pressure to reduce fraudulent financial statements has encouraged many regulators to improve the detection on fraudulent financial statements. Tredway Commission recommends Accounting Standards Board (ASB) to require the use of analytical procedures on all types of audits to improve financial reporting 
fraud detection (Wheeler and Haan, 1996 in Limming Guan et.al, 2007). Analytical procedure is a comparison of the carrying amount / calculation ratio that is derived from amounts recorded which is compared with the expectations that have been developed by auditor (in accordance with Section 329 PSA). According to Thornhill, 1995 in Kaminzki, et al, 2004, the analytical procedure has become a useful tool for identifying fraudulent financial statements. This procedure involves the analysis of trends, ratios, and the reasonableness test derived from the financial and operations entities data. According to SAS 99, fraud incident by the time, the auditor must consider the results of analytical procedures in identifying the risks of material misstatement due to fraud (AICPA, 2002).

Some studies identify fraudulent financial statements all this time that have been done only in terms of the approach beyond the publication report. For example red flag approach, although red flag approach tries some views on tendency in fraudulent financial reporting, list of the existing indicators include a large number of subjective judgment and the information tend to be more non-public and only be available for the auditor or the person in the company (Persons, 1995). As if research conducted by Wiloppo (2006), examines the tendency of fraudulent financial statement that is measured from the effectiveness of internal controls and compensation provision. However, to obtain information from the internal party is extremely hard to be come by or obtained by the public. Likewise, it would be difficult for investors and regulatory or stock exchange agency in order to access red flags for identifying the companies involved in financial reporting fraud (Stanny, 2011). Consequently, it is necessary to conduct a research by using published financial statement data that more easily gotten by the public. Thus the public and the policy or regulators makers can obtain a model that is able to identify tendency in fraudulent financial statement.

Persons (1995) in his research, concludes that turnover capital, financial leverage, asset composition and size of the company have an influence on the fraud tendency in accounting. Soselisa and Mukhlasin (2008) in his research that uses publication information in Indonesia also conclude that size of a company and composition of its assets effect on the fraud tendency in accounting. Some of these studies are still a little in taking variables of financial ratio analysis as a tool for identifying fraud, so it causes weakness in identifying fraudulent financial statements by using financial ratios as a means of measurement considering there are some kind of ratios that are able to identify fraud. Accordingly, it still needs to add some more comprehensive financial ratios to identify fraudulent financial statements that have not been done by previous researchers. Research on the tendency of fraudulent financial statements using publication information is not only measured by financial variables such as carried out by that the researchers, but also using quantified non-financial variables.

Committee of Sponsoring Organization of The Treadway Commission (COSO) in 2010 identified cases of suspected fraud in financial reporting done by companies listed on United States Securities and Exchange Commission (SEC) in Accounting and Auditing Enforcement Releases (AAERs) in the period of 1998-2007. The result shows that 72\% of the fraud cases have involved the CEO and the board of directors that are usually mostly held by insiders or those who have ties to the company. Furthermore, Bart Victor and Bruce Lamont (in Geriesh, 2003) who write about "Board Composition and The Commision of Ilegal Acts: An Investigation of Fortune 500 Companies" for the Academy of Management Journal in 1986, find 
that companies are punished for their illegal acts, illegal infraction histories of previous company, as well as the corporate culture that justifying a wrong activity. The research results proves that the illegal activities of companies started with misdemeanors and then let that be an illegal corporate culture and ultimately lead to fraudulent financial reporting (Geriesh, 2003). Sutherland 1940 in Geriesh 2003, in his book American Sociological Review states that corporate and industry culture contribute to their white-collar crime. From the phenomena result that has been done by the researchers, it can be concluded that corporate culture affects a company or industry to commit illegal violations included fraudulent financial statements.

Statement of the COSO research findings (2010) is also supported by researchers today, by Troy (2003) in Soselisa and Mukhlasin (2008) finds empirical evidence that fraud tendency in accounting also influenced by managerial factors, such as the age of the CEO and his educational background. Results of research conducted by COSO is also reinforced by Geriesh research (2003) who finds evidence that the percentage large of the founder of a company in board of directors and the small of accountant ratio in the board of directors have an influence on the tendency of fraudulent practices in accounting. Soselisa and Mukhlasin (2008) re-examine the research conducted by Geriesh (2003) which also proxies corporate culture with the data of publication in Indonesia through a number of related party transactions, presentation number of founders in the board of directors and the number of professional accountants in the composition of the board of directors. His research finds evidences that the company that has a number of few transactions with parties that have special relationship will have a tendency to do greater accounting fraud. While the relationship between board of director ratio and the number of accountants in the directors is found to have no influence in the tendency of fraudulent accounting.

Background on the case above, in this study, the author tries to combine and develop quantified financial and non-financial aspects to identify fraudulent financial statements so that the study is a replication of the research that has been done by Soselisa and Mukhlasin (2008) which combines financial and non-financial aspects to in identifying financial statement fraud with publication financial statement data in Indonesia. This research was conducted with theoretical study on fraudulent financial reporting through the information contained in the publication financial statements so can be used as a bridge to identify the tendency of fraudulent financial reporting. The problems of this study are whether financial ratios and corporate culture partially affect the financial reporting fraud and whether financial ratios and corporate culture simultaneously affect the financial reporting fraud.

Theory of fraud triangle has been introduced in a professional literature, namely SAS No. 99, Consideration of Fraud in a Financial Statement Audit. Cressey (1953) in Skousen, et al (2009) concludes that fraud has three general properties that are incentive/pressure, opportunity and attitude/rationalization. Pressure is an impulse that causes someone to commit fraud, for example, having accumulating debts, lavish lifestyle, a dependency on drugs, and so on. Usually, the fraud motivated by the needs or financial problems, although it is not uncommon that only motivated by greed. But according to SAS No. 99, actually there are several types of pressure conditions that can generally result in fraud. The conditions are financial stability, external pressure, personal financial need, and financial targets (Resti, 2011). 
Theory of fraud triangle that discusses about opportunity, explains that it is usually caused by several things, such as the lack of internal controls of an organization, lack of or no supervision, or the abuse of authority. Opportunity is an element in fraud triangle that has biggest possibility to be minimized by applying the correct process, procedure, monitoring and early detection efforts against fraud. According to SAS No. 99, the opportunities of fraud in financial reporting can occur in three categories, namely nature of industry, ineffective monitoring, and organizational structure.

General nature of fraud the last is rationalization. Rationalization is an important element in the occurrence of fraud. Rationalization is a condition in which the perpetrator of fraud justifies all the actions that have been carried out. Usually, condition that drives is when the perpetrator has had a long working life accompanied by a feeling that he should have a right to get something more than that already he can get right now, such as in the form of the salary scale, position, promotions, etc. On the other hand, he argues that the company where he works has gained huge profits, so it will not be a problem if he involves to take a little of the profits of the company.

Financial Statement Fraud is all officials and/or executives actions of a company or a government institution that aims to cover the company's financial condition by conducting financial engineering activity even to the activity of its financial statement presentation for gains. Accounting fraud according to Indonesian Accountants Association (IAI, 2009) is as follows: (1) Misstatements due to the impact of fraud in financial reporting, that is misstatements or efforts to eliminate deliberately both the amount and disclosures contained in its financial statements with the aim to fool the users of financial statements; (2) Misstatements due to the impact of the treatment to the assets that are not properly (usually referred to as embezzlement or misappropriation of assets or embezzlement) associated with the activity of assets theft of an entity that results in the presentation of financial statements that do not conform with generally accepted accounting principles in Indonesia.

Institutional theory is a theory that emphasizes corporate culture in a behavior. Corporate culture is a common perception that has been embraced by members of an organization and become a system of shared meaning. Corporate culture is also referred to as a system of meaning that has been owned by an organization that will differentiate the organization with other organizations. Organizational culture can also be regarded as an integrated pattern of human behaviour in an organization / company including all thoughts, actions and discussion that can be learned and taught to future generations (Ruslan, 2011). Each company develops accounting rules and procedures that accepted socially becoming a way to understand the situation of the company's accounting. Over time they began to form part of the culture of corporate accounting that affecting the next accounting decisions. When departed accounting culture began to evolve, companies are more likely to consider illegal financial reporting to be a legitimate accounting policy (Geirish, 2003).

\section{METHODS}

Output variables in this study were output value of textile industry and textile products. Input variables used among others: cost of raw and auxiliary materials, expenses for labour, electric power purchased and 
expenses of fuel and lubricants. This study used variable dependent of financial reporting fraud. Financial reporting fraud is a dummy variable in which the variable used is a categorical variable. The measurement was if the sample companies did financial reporting fraud, it would be given score 1 . While, the sample companies that did not do financial fraud reporting would be given score 0 . The Company categorized committing fraud in its financial reporting based on press release of Capital Markets Supervisory Board (Bapepam) 2006-2010 is:

1. Misstatements (mispresentation) or misinformation that is significant in its financial statements.

2. Misapplication of generally acceptable accounting principles that has to do with the amount, classification, presentation and disclosure.

Violations in the press release of Bapepam report 2006-2010, which did not include a financial statement fraud include:

1. Delays in submitting the annual financial statements

2. Delays in presenting use realization report and the results of a public offering or an affiliate transaction reports.

3. Usage of Public Accounting Firm (KAP) that is not registered with Bapepam and has not completed a statement of the board of directors in the report of audited results.

4. Data of financial statements and its fraud information is not presented in full imposture.

These four categories that are not classified as financial reporting fraud used as a basis to conduct purposive sampling for populations companies that perform fraudulent financial reporting. This study used financial ratios and organizational culture as the independent variable. In this study, Financial Ratios proxied into some kind of financial ratios to identify companies that commit fraud. Definition of several types of financial ratios according to Husnan (1994) in Yulia (2005) is as follows:

\section{Liquidity Ratio (CR)}

Liquidity Ratio is the ability of a company to meet its short-term liabilities by using current asset owned. Liquidity Ratio measurement used is current ratio. When it formulated, the ratio is as follows:

$$
\text { Current Ratio }=\frac{\text { Current Asset }}{\text { Current Liabilities }}
$$

\section{Leverage Ratio (LEV)}

In this study, leverage ratio is the ratio of debt total to assets total. This ratio is used to measure how far the assets of a company have been financed with debt. The leverage ratio in this study formulated as follows:

$$
\text { Leverage }=\frac{\text { Total Liabilities }}{\text { Total Assets }}
$$

\section{Productivity Ratio (gross profit margin/GPM)}

This ratio is used as a measure of the product profitability level before burdened by various other charges. This ratio describes the company's ability to earn profits and its gross profit rate from sales activity, using the assets, as well as turning the capital. The productivity ratio is formulated as follows: 


$$
G P M=\frac{\text { Gross Margin }}{\text { Sales }}
$$

\section{Assets Composition Ratio (ARTA, INTA)}

Asset composition ratio describes the ability of companies to use corporate assets to generate revenue or profit. The ratio is formulated as follows:

$$
\begin{aligned}
& A R / T A=\frac{\text { Account Receivable }}{\text { Total Asset }} \\
& I N / T A=\frac{\text { Inventory }}{\text { Total Asset }}
\end{aligned}
$$

\section{Capital Turnover Ratio (SALTA)}

Capital turnover ratio is an overview of activities that have been carried out by a company in carrying out good operations in sales activities. This ratio is also used to measure the extent of a company's effectiveness in using its sources of funds. The Capital Turnover ratio formula is as follows:

$$
S A L / T A=\frac{\text { Sales }}{\text { Total Aset }}
$$

\section{Ratio of Productivity (INSA, SAAR)}

This ratio measures how effective a company in the use of resources that have been set in the company's discretion. This ratio compares between the sales and the assets supporting the sales. The formula used is as follows:

$$
\begin{aligned}
I N / S A & =\frac{\text { Inventory }}{\text { Sales }} \\
S A / A R & =\frac{\text { Sales }}{\text { Account Receivable }}
\end{aligned}
$$

\section{Profitability Ratio (ROA)}

Profitability ratio is a ratio that shows company's ability to earn profits through all of the capabilities and use of existing resources such as sales activities, cash, capital, number of employees, etc. The formula used is as:

$$
R O A=\frac{\text { Net Income }}{\text { Total Asset }}
$$

\section{Related Party Transactions (RTP)}

Research conducted by Geriesh (2003) found that companies which often conduct related party transactions will be engaged in fraudulence of financial statements. RTP variables measured with the number of transactions with various parties which have special relationship to the company.

\section{The Founder of the Company (\% OWN)}

The founder of companies typically have a higher commitment to the company he founded as compared with other parties. Because of the strength of that commitment that allows the founder of the company is willing to do anything for the sustainability of the company, even doing illegal and distorted 
actions (Soselisa and Mukhlasin, 2008). Variable of \% OWN measured by comparing the amount of the company's founder in the board of directors and total board of directors.

\section{Professional Accountant (CPA)}

A company that has professional accountant will encourage the company to be able to adjust corporate culture that exists with applicable standards in behavioural accounting which can be acceptable in code of ethics for accountants (Geriesh, 2003). CPA variables measured from the large number of individuals in the board of directors and senior management that have an accountant degree (Akt). Testing of the hypothesis in this study used logistic regression because to determine the effect of financial and corporate culture ration against fraud of financial statements. Logistic regression (logit) selected if the variable which was an ordinal scale was the dependent variable. Logit model would be used in this study can be described by the following equation:

Fraud $=\boldsymbol{\alpha}+\boldsymbol{\beta}_{\mathbf{1}}(\mathrm{CR})+\boldsymbol{\beta}_{2}(\mathrm{LEV})+\boldsymbol{\beta}_{\mathbf{3}}(\mathrm{GPM})+\boldsymbol{\beta}_{4}(\mathrm{ARta})+\boldsymbol{\beta}_{\mathbf{5}}(\mathrm{INta})+\boldsymbol{\beta}_{\mathbf{6}}(\mathrm{SALta})+\boldsymbol{\beta}_{7}(\mathrm{INsa})+\boldsymbol{\beta}_{\mathbf{8}}$ $(\mathrm{SAar})+\boldsymbol{\beta}_{9}(\mathrm{ROA})+\boldsymbol{\beta}_{10}(\mathrm{THI})+\boldsymbol{\beta}_{11}(\% \mathrm{OWN})+\boldsymbol{\beta}_{12}(\mathrm{CPA})+\varepsilon$

Relationships between variables in this study are described in the following framework:

Figure 1. Theoretical Framework

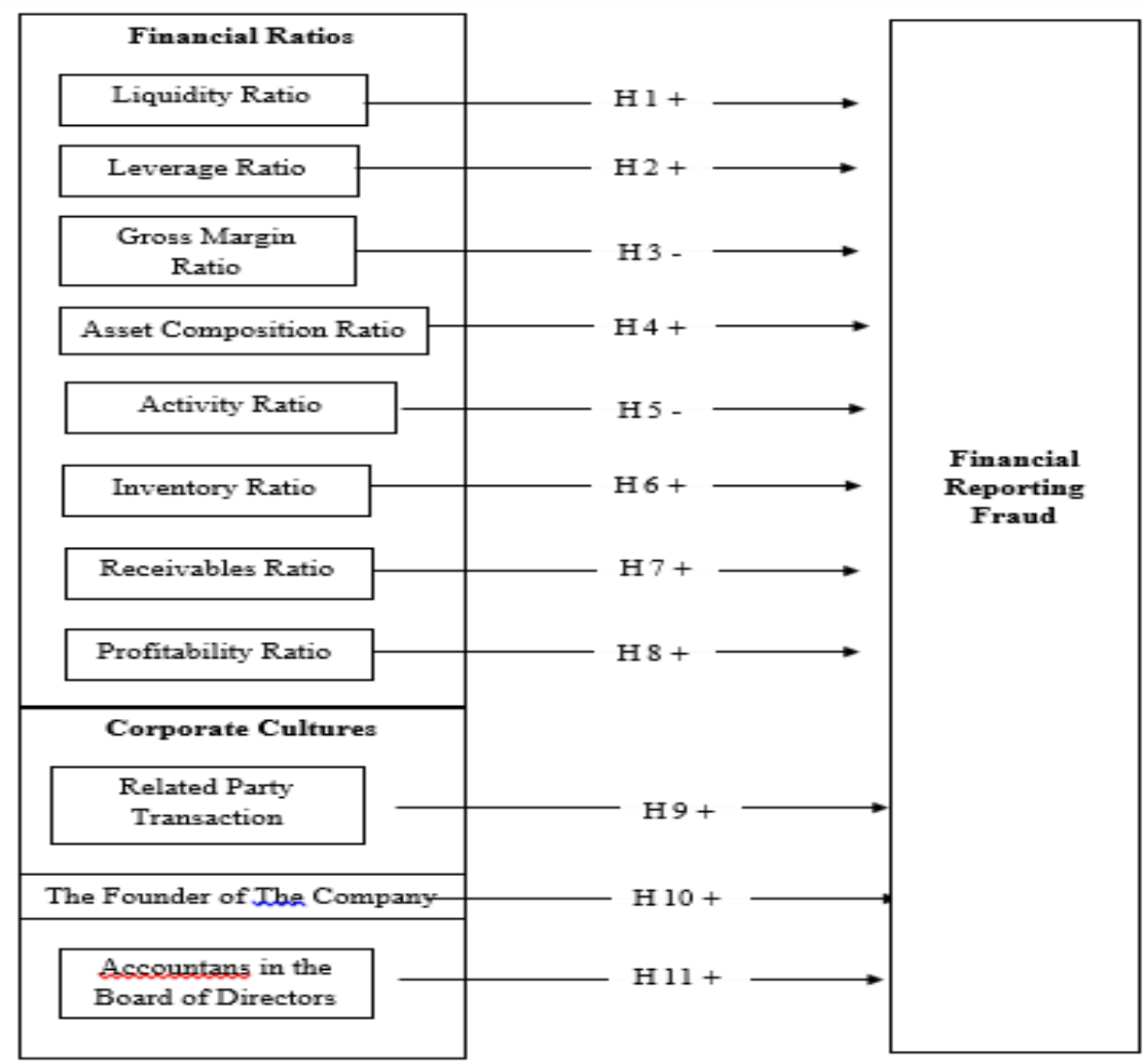




\section{RESULTS AND DISCUSSION}

Based on the result of logistic regression model output, chi-square value obtained from Hosmer and Lemeshow test was 2,568 with a significance value of 0.958 with a greater significance level than the level $\alpha$ of 0.05 then Ho was accepted which means that the regression model in this study was feasible used for next analysis because there was no real difference between the observed classification and the predicted classification. This study used logistic regression model to test the model by observing relationship possibilities of fraud in financial reporting which was done by a company in a period through corporate culture and financial ratios that they owned. Based on Table 4.10, it was obtained regression model as follows:

Fraud $=158 \alpha+0,399 \mathrm{CR}+0,746 \mathrm{LEV}-4,193 \mathrm{GPM}+6,115 \mathrm{ARta}-2,865 \mathrm{INta}-1,306 \mathrm{SALta}+0,519$ INsa +0,009 SAar + 0,952 ROA - 0,21 THI - 0,790 OWN + 0,336 CPA + e

Table 1. The Result of Overall Fit Significance Test

\begin{tabular}{|l|l|l|l|l|}
\hline & & Chi-square & df & Sig. \\
\hline \multirow{3}{*}{ Step 1 } & Step & 23.896 & 12 & .021 \\
\cline { 2 - 5 } & Block & 23.896 & 12 & .021 \\
\cline { 2 - 5 } & Model & 23.896 & 12 & .021 \\
\hline
\end{tabular}

Table 2. The Result of Model Prediction Strength Test

\begin{tabular}{|c|c|c|c|c|c|}
\hline & \multirow{3}{*}{\multicolumn{2}{|c|}{ Observed }} & \multicolumn{3}{|l|}{ Predicted } \\
\hline & & & \multicolumn{2}{|l|}{ FRAUD } & \multirow{2}{*}{$\begin{array}{l}\text { Percentage } \\
\text { Correct }\end{array}$} \\
\hline & & & $\begin{array}{ll}\text { NOT } & \text { DO } \\
\text { FRAUD } & \end{array}$ & DO FRAUD & \\
\hline \multirow[t]{3}{*}{ Step 1} & \multirow[t]{2}{*}{$\begin{array}{l}\text { FRA } \\
\text { UD }\end{array}$} & $\begin{array}{ll}\text { NOT } & \text { DO } \\
\text { FRAUD } & \end{array}$ & 33 & 6 & 84.6 \\
\hline & & DO FRAUD & 15 & 24 & 61.5 \\
\hline & \multicolumn{2}{|c|}{ Overall Percentage } & & & 73.1 \\
\hline
\end{tabular}

Source: secondary data processed

Table 3. The Result of Hypothesis Test

\begin{tabular}{|l|l|l|l|l|l|l|l|}
\hline \multicolumn{2}{|l|}{} & B & S.E. & Wald & Df & Sig. & Exp(B) \\
\hline \multirow{3}{*}{ Step $1^{\text {a }}$} & CR & .399 & .202 & 3.886 & 1 & .049 & 1.490 \\
\cline { 2 - 8 } & LEV & .746 & 1.160 & .414 & 1 & .520 & 2.109 \\
\cline { 2 - 8 } & GPM & -4.193 & 2.042 & 4.218 & 1 & .040 & .015 \\
\cline { 2 - 8 } & Arta & 6.115 & 3.336 & 3.360 & 1 & .067 & 452.749 \\
\cline { 2 - 8 } & Inta & -2.865 & 2.765 & 1.074 & 1 & .300 & .057 \\
\cline { 2 - 8 } & SALta & -1.306 & .627 & 4.341 & 1 & .037 & .271 \\
\cline { 2 - 8 } & Insa & .519 & .603 & .739 & 1 & .390 & 1.680 \\
\cline { 2 - 8 } & Saar & .009 & .007 & 1.879 & 1 & .170 & 1.009 \\
\hline
\end{tabular}




\begin{tabular}{|l|l|l|l|l|l|l|l|}
\hline \multirow{7}{*}{} & ROA & .952 & 1.258 & .573 & 1 & .449 & 2.591 \\
\cline { 2 - 8 } & THI & -.021 & .034 & .398 & 1 & .528 & .979 \\
\cline { 2 - 8 } & OWN & -.790 & .993 & .633 & 1 & .426 & .454 \\
\cline { 2 - 8 } & CPA & .336 & .367 & .841 & 1 & .359 & 1.400 \\
\cline { 2 - 8 } & Constant & .158 & 1.110 & .020 & 1 & .887 & 1.171 \\
\hline
\end{tabular}

Table 4. The Result of Chi Square Test

\begin{tabular}{|c|c|c|c|}
\hline Step & $\begin{array}{c}-2 \quad \text { Log } \\
\text { likelihood }\end{array}$ & $\begin{array}{c}\text { Cox \& } \\
\text { Snell R Square }\end{array}$ & $\begin{array}{c}\text { Nagelkerke } \\
\text { R Square }\end{array}$ \\
\hline 1 & $84.235^{\mathrm{a}}$ & .264 & .352 \\
\hline
\end{tabular}

Source: secondary data processed

Value of Nagelkerke R Square that obtained from the testing result could be seen in Table 4, it was obtained value amounted to 0.352 . The value could be interpreted that the variability of dependent variable in this study could be explained by the variability independent variables used by $35.2 \%$. While, $64.8 \%$ of the variability of the dependent variable can be explained by others independent variables that are not included in the regression model in this study.

While testing of the hypotheses is described below:

\section{The First Hypothesis Testing}

Statistical test result showed that liquidity pointed positive value and significant value $(0,049)$ was less than $5 \%$ with B value (coefficient) of 0.399 . It showed that the companies did accounting fraud tended to high levels of liquidity. The result of this study supports the result of the study conducted by Persons (1995) which concludes the positive influence in which the high level of liquidity will lead to fraudulent financial reporting. It also supports the research conducted by Kreutzfelt and Wallace (1986) and Stanny (2011), which state that a company with liquidity problems significantly has greater mistake level in the presentation of its financial statements rather than a company that does not have liquidity problems.

2. The Second Hypothesis Testing

Statistical test result showed that the value of regression coefficient owned by leverage variable indicated positive signs, and had significance probability value of 0,520 which was greater than $5 \%$. It indicated that leverage did not have influence on the financial reporting fraud. The result of this study is consistent with studies conducted by Skousen (2009) and Soselisa and Mukhlasin (2008) who find empirical evidence that leverage variable does not significantly affect on the financial reporting fraud. However, this result differs from the result of the research found by Persons (1995), where the result of the research shows that financial leverage has an influence on fraudulent financial statements.

3. The Third Hypothesis Testing

Statistical test result showed that regression coefficient of gross profit margin variable indicated a negative sign with sig. value $(0,040)$ greater than $5 \%$. It indicated that the value of low gross profit margin negatively affected on the trend of financial reporting fraud. The result of the study is contradict with the study conducted by Skousen et.al (2009), who concludes that financial stability stress factors that is proxied 
by the ratio of gross profit margin does not affect the financial reporting fraud. However, it is consistent with the result of the study found by Loebeccke, et al, 1989 in Skousen, et al (2009) where the conclusion is that gross profit margin negatively affects financial reporting fraud.

4. The Fourth Hypothesis Testing

Statistical test result showed that regression coefficient of asset composition variable indicated positive coefficient with sig. value (0.67) was greater than $5 \%$ for accounts receivable and negative coefficient with sig value (0.30) for accounts receivable. It indicated that assets composition did not have effect on the tendency of financial reporting fraud. The result of this study contradicts with the results of the study found by Persons (1995), Soselisa and Mukhlasin (2008) who found evidence that high asset composition affects the fraudulent financial statements. However, it is consistent with the research conducted by Kaminzki et.al (2004), that suggests that asset composition which are measured with ARTA and INTA does not affect the fraudulent financial statement.

5. The Fifth Hypothesis Testing

Statistical results showed that regression coefficient of Capital Turnover was (-1.306) with significance (0.37). It was proven that the lower the Capital Turnover had a negative influence on the financial reporting fraud. The result of this study is consistent with research of Persons (1995), Kaminzki et.al (2004), Soselisa and Mukhlasin (2008), in which the research results show that activity ratio of a company which is measured by dividing sales by total assets has a significant negative effect on fraudulent financial statements. These findings also indicate that the management that is facing pressure of financial stability will encourage companies to commit financial reporting fraud.

6. The Sixth Hypothesis Testing

The variable of inventory to sales (INsa) ratio had sig. value of 0.390 . The value $>$ from real level $(\alpha)$ of 0.05 , and had B-value (determination coefficient) of 0.519. It can be interpreted that INsa variable did not have significant effect on the level of 5\%. The sixth hypothesis in this study was rejected. The result of this study is consistent with research of Kaminzki et.al (2004) and Skousen et.al (2009) which state that inventory to sales ration did not effect on the financial statement fraud. Therefore, this study failed to prove the effect of changes in inventory to sales on the financial statement fraud.

7. The Seventh Hypothesis Testing

Variables of the ratio of sales to accounts receivable (SAAR) had significance probability value of 0.170 which was smaller than the significance level $(\alpha)$ of 0.05 , and had B value (coefficient) of 0.009 . This value could be interpreted that the Saar variable was not significant at the $5 \%$ level so that the alternative hypothesis was rejected. It could be concluded that SAar did not have effect on fraudulent financial reporting. The result of this study is consistent with research of Kaminzki et.al (2004) showed that the ratio of sales to accounts receivable (SAar) did not effect on the fraudulent financial statements. This result failed to support the study conducted by Albrect (2009), which states that one of the ways to commit fraud related to the revenues is by recording receivable and fictitious income. 


\section{The Eighth Hypothesis Testing}

Statistical analysis showed ROA had significance (0.449) and B (coefficient) was positive so that it can be concluded that ROA did not affect the financial reporting fraud. The result is consistent with the result obtained by Persons (1995) and Kaminzki et.al (2004) which shows that the profitability ratio (ROA) does have effect on fraudulent financial reporting.

9. The Ninth Hypothesis Testing

Statistical analysis showed that special parties transactions had a significance level which was $>5 \%$ so that variable of special parties transactions did not affect the financial reporting fraud. The result of this study contradicts research conducted by Gerish (2003) and Lou (2009) which shows that the transaction with a related party affects the financial statement fraud. However, it is consistent with research conducted by Soselisa and Mukhlasin (2008) which concludes that a company that tends to commit accounting fraud is when the number of transactions with special party is relatively few.

10. The Tenth Hypothesis Testing

The statistical analysis showed that the variable of $\mathrm{OWN}>5 \%$ so that it did not have any effect on the financial reporting fraud. This result is consistent with the result of the study found by Soselisa and Mukhlasin (2008). However, this result is not in accordance with the result of the study found by Gerish (2003) which shows that the percentage of business owners in the composition of the board of directors has an influence on fraudulent financial statements.

\section{The Eleventh Hypothesis Testing}

The statistical analysis showed that the variable of OWN $>5 \%$ so that it did not have any effect on the financial reporting fraud. This result is also consistent with the study result of Soselisa and Mukhlasin (2008) but, it is contradict with the study conducted by Gerish (2003) which shows result that the number of accountants in the composition of the board of directors of a company has an influence on fraudulent financial statements of that company.

\section{CONCLUSIONS}

Fraudulent financial reporting has caused big enough problems for the economic progress of a country and has become a social problem and economic concern. Cases of fraudulent financial reporting prove the failure of audit quality in detecting fraudulent financial statements. American Institute of Certified Public Accountants (AICPA) published Statement Audit Standard (SAS 99) to improve detection of fraudulent financial reporting based on fraud risk factors of the fraud Triangle Theory. The pressure in the institutional environment also encourages a company to commit fraud because the development of fraudulent financial reporting culture also creates a corporate culture to legalize financial reporting which is not generally acceptable.

This study examined the effect of fraud risk factor that is the pressure of financial stability which is proxied by financial ratios (liquidity, leverage, asset composition, gross profit margin, capital turnover, receivable ratio, inventory ratio and profitability ratio) based on the fraud triangle theory. The influence of 
corporate culture on fraudulent financial reporting which is proxied by (related party transactions, directors who become the founder of the company and the number of the board of directors who titled accountants) are based on institutional theory. The sample used in this study were a total of 39 companies that commit fraud in financial reporting and a total of 39 companies that did not commit fraud in financial reporting. The population used is all the companies obtained from the company that sanctioned accounting fraud from Capital Markets Supervisory Board (Bapepam) in 2006-2010, which is taken by purposive sampling that is excluded banking and insurance company, a sanction which is not fraud financial statements and companies that do not have complete fraud sanction data. For the companies that do not commit fraud, the population taken is companies registered in Indonesia Stock Exchange during 2006-2010, then it is retrieved a company that has same size asset, same industry and the same year period with a company that has done fraudulent financial reporting.

This study found the results that financial ratios which are proxied by liquidity ratio, gross profit margin ration and capital turnover have an effect on fraud in financial reporting. While, the variables of asset composition, leverage, inventory ratio, accounts receivable ratio and profitability ratio do not effect on the fraudulent financial reporting. The result of this study also indicates that the variables of corporate culture that are proxied by related party transactions, the number of board of directors who become the founder of the company and the number of board of directors who titled accountant do not affect the fraud in financial reporting.

\section{REFERENCES}

Albrecht W.Steve and Albrecht Chad O., 2002 . "Fraud Examination. Thomson South- Western. Artikel BPKP. Fraud (Kecurangan): Apa dan Mengapa? Sie Infokum - Ditama Binbangkum.

Amrizal, 2004. Pencegahan dan Pendeteksian Kecurangan Oleh Internal Auditor. Jakarta. accessed $13^{\text {th }}$ April 2011 Bapepam. Siaran Pers Badan Pengawas Pasar Modal 2006-2010. Badan Pengawas Pasar Modal.

Beasly et.al, COSO. 2010. Fraudulent Financial Reporting 1998-2007, An Analysis of U.S. Public Companies. Commitee of Sponsoring Organization of The Treadway Commission (COSO).

Budi Santosa, Purbayu and Ashari. 2005. Analisis Statistif dengan Microsoft Excel dan SPSS. Yogyakarta. Andi Offset Geriesh, Lofti. 2003. Organization Culture and Fraudulent Financial Reporting”. Nova South Eastern University Ghozali, Imam, 2006. Aplikasi Analisis Multivariate dengan Program SPSS.Semarang. Badan Penerbit Universitas Diponegoro.

Guan, Liming et.al. 2008. Can Investors Detect Fraudusing Financial Statements: An Exploratory Study. Public Interest Accounting,Volume13,17-34

Indonesian Capital Market Directory (ICMD) 2006 - 2010. BEI Information Center Jogiyanto, 2005. Metodologi Penelitian Bisnis, Yogyakarta, BPFE

Juniarti and Corolina, 2005. Analisa Faktor-Faktor Yang Berpengaruh Terhadap Perataan Laba (Income Smoothing) Pada Perusahaan-Perusahaan Go Public. Jurnal akuntansi \& keuangan, vol. 7, no. 2, nopember 2005: 148-162 Kurniawati, Ema. 2011. Analisis Faktor-Faktor Yang Mempengaruhi Financial Statement Fraud dalam Perspektif Fraud Triangle. Skripsi. Fakultas Ekonomi dan Bisnis. Universitas Diponegoro Semarang. 
Kaminzki et.al. 2004. Can financial ratios detect Fraudulent financial reporting?. Managerial Auditing Journal Vol.19No.1,2004 pp.15-28

Koroy, Tri Ramaraya. n.d. Pendeteksian Kecurangan (Fraud) Laporan Keuangan oleh Auditor Eksternal. STIE Nasional Banjarmasin.

Leosinga, Ruslan. 2011. Artikel Budaya Organisasi. diakses tanggal 10 Agustus 2012.

Lou and Wang. 2009. Fraud Risk Factor Of The Fraud Triangle Assessing The Likelihood Of Fraudulent Financial Reporting. Journal of Business \& Economics Research - February, 2009 Volume 7, Number 2

Mandasari, Laras. 2011. Faktor Transaksi dengan Pihak Istimewa, Financial Leverage, Strategi Akuisisi dan Auditor Terhadap Kecenderungan Kecurangan Akuntansi (Studi Pada Perusahan yang Terdaftar di Bursa Efek Indonesia. Skripsi. Fakultas Ekonomi. Universitas Pembangunan Nasional "Veteran” Jakarta.

Molida, Resti. 2011. Pengaruh Financial Stability, Personal Financial Need Dan Ineffective Monitoring Pada Financial Statement Fraud Dalam Perspektif Fraud Triangle. Skripsi. Fakultas Ekonomi. Universitas Diponegoro. Semarang

Mukhlasin. 2007. Determinan Ekonomi Pemilihan Kebijakan Akuntansi: Analisis Single Motive dan Multiple Motive Studi Pada Perusahaan Manufaktur di

Bursa Efek Jakarta. Disertasi. Program Pasca Sarjana Doktor Ilmu Ekonomi-Konsentrasi Akuntansi. Universitas Diponegoro Semarang

Norbarani, Listiana. 2012. Pendeteksian Kecurangan Laporan Keuangan dengan Analisis Fraud Triangle yang diadopsi dalam SAS No.99. Skripsi. Fakultas Ekonomika dan Bisnis. Universitas Diponegoro Semarang.

Persons, O.S. 1995, "Using financial statement data to identify factors associated with fraudulent financial reporting” Journal of Applied Business Researc,Vol.11No.3,pp.38-46

Purwanti, Yulia.2005. Analisis Rasio Keuangan dalam Memprediksi Kondisi Keuangan Financial Distress Perusahaan Manufaktur yang Terdaftar di Bursa Efek Jakarta. Skripsi. Fakultas Ekonomi. Universitas Islam Indonesia. Yogyakarta.

Skousen, et.al, 2009. Detecting And Predicting Financial Statement Fraud:The Effectiveness Of The Fraud Triangle And Sas No.99. Emerald Journal Volume13,53-81.

Spathis T, Charlambos. 2002. Detecting False Financial Statements using published data: Some Evidence from Greece. Managerial Auditing Journal 17 179-191.

Rangga Soselisa, and Mukhlasin, 2008. Pengaruh Faktor Kultur Organisasi, Manajemen, Strategik, Keuangan, dan Auditor Terhadap Kecenderungan Kecurangan Akuntansi: Studi Pada Perusahaan Publik di Indonesia. Unika Atma Jaya Jakarta.

Stanny Gagola, Antonius, 2011. Analisis Resiko Kecurangan Laporan Keuangan Pada Perusahaan yang Terdaftar di Burse Efek Indonesia. Tesis. Program Pasca Sarjana Magister Sains Akuntansi, Universitas Diponegoro Semarang.

Sukartha, Made. 2007. Pengaruh Manajemen Laba, Kepemilikan Manajerial, dan

Ukuran Perusahaan pada Kesejahteraan Pemegang Saham Perusahaan Target Akuisisi. Jurnal Riset Akuntansi Indonesia Vol. 10, No. 3, September 2007 . P. 243-267

Tuanakota M., Theodorus. 2007. Akuntansi Forensik dan Audit Investigatif. Seri Departemen Akuntansi FE UI. Thornhill,W.T. 1995, Forensic Accounting-How to Investigate Financial Fraud, Richard. Irwin, NewYork, NY. Uma Sekaran, 2000, Research Methods For Business, $4^{\text {th }}$ Ed, Book 1, Jakarta: Salemba Empat. 
The Impact Of Corporate Cultures And Financial Ratios On The Fraudulent Financial Reporting Agung Prajanto, Ririh Dian Pratiwi

Wilopo. 2006. Analisis Faktor-faktor yang Berpengaruh Terhadap Kecenderungan Kecurangan Akuntansi”. STIE Perbanas.

Wilardjo, Liek 2011. Catatan Teori Organisasi dan Manajemen (Teori Institusional). Blog.at wordpress.com accessed. 29 Februari 2012 